\title{
Mnichovská dohoda v kontextu evropských dějin 20. století
}

Dne 21. 9. 2018 se otevírala v Senátu Parlamentu ČR výstava s názvem Mnichovská dohoda v kontextu evropských dějin v 20. století pod záštitou 1. místopředsedkyně Senátu Parlamentu ČR Miluše Horské a předsedkyně Akademie věd ČR Evy Zažímalové. Autorem výstavy je Jan Němeček z Historického ústavu AV ČR (HÚ AV ČR) a mnichovskou dohodu zobrazil v mezinárodním, národním a politickém kontextu včetně jejích bezprostředních důsledků.

Po prohlídce výstavy v Mytologické chodbě Valdštejnského paláce byla zahájena odborná diskuze v Rytířské síni vedená moderátorem Emilem Voráčkem (HÚ AV ČR). Jan Němeček přednesl svůj př́spěvek o vztahu československého státu a národností v něm žijících na sklonku 30. let, poté zhodnotila slovenskou otázku před Mnichovem a za druhé republiky Zlatica Zudová-Lešková (HÚ AV ČR). Jaroslav Šebek (HÚ AV ČR) zajímavě pojal německou menšinu v Československu mezi Berlínem a Prahou, Eva Irmanová (HÚ AV ČR) zhodnotila postavení mad’arské menšiny v Československu a dopady Vídeňské arbitráže. První blok uzavřel Piotr Majewski (Uniwersytet Warszawski) s velmi zajímavým prŕspěvkem k tématu Polsko, Sovětský svaz a konec První republiky.

Druhý blok zahájil Alain Soubigou (Université de la Sorbonne), aby zhodnotil postoj západních velmocí a otázku appeasementu ve vztahu k Československu. Jan Kuklík (Právnická fakulta UK) se z pracovních důvodů omluvil, proto jeho př́íspěvek přednesl Jan Němeček na téma zápasu československé exilové vlády za oduznání Mnichova v letech druhé světové války.

Před závěrečnou diskuzí vystoupil Jindřich Dejmek (HÚ AV ČR) s tématem Československo a prosazení nulity Mnichova ve vztahu k německým státům. Následovala plodná diskuze plná zajímavých dotazů a postojů k mnichovské dohodě a poutavých hypotéz, kterou završil závěrečným slovem s reminiscencemi na konec 30. let věhlasný historik Robert Kvaček. K pracovnímu semináři a výstavě samotné je nutno dodat, že výstava bude v Senátu otevřena až do 13. ledna 2019.

doi: 10.14712/2464689X.2018.60

Daniela Němečková 